\title{
A Randomized clinical trial of antioxidant therapy in patients with septic shock. Reference study to propose adjuvant therapy in patients with critical organic damage by COVID-19
}

\author{
Alfredo Aisa-Alvarez \\ Critical Care Department, American British Cowdray (ABC) Medical Center \\ Israel Perez-Torres
}

Cardiovascular Biomedicine Department Instituto Nacional de Cardiología Ignacio Chávez

Gilberto Camarena-Alejo

Critical Care Department, American British Cowdray (ABC) Medical Center Juvenal Franco-Granillo

Critical Care Department, American British Cowdray (ABC) Medical Center

\section{Enrique Martínez-Rodríguez}

Critical Care Department, American British Cowdray (ABC) Medical Center

\section{Ricardo Gamboa}

Physiology Department Instituto Nacional de Cardiología Ignacio Chávez.

\section{Veronica Guarner-Lans}

Physiology Department Instituto Nacional de Cardiología Ignacio Chávez

\section{MariaElena Soto ( $\nabla$ mesoto50@hotmail.com )}

Researcher Chief Cardiovascular Line American British Cowdray (ABC) Medical Center, I.A.P. and Immunology Department Instituto Nacional de Cardiología Ignacio Chávez

\section{Research}

Keywords: Antioxidants, Adjuvant therapeutic, Septic Shock, organic damage

Posted Date: August 19th, 2020

DOl: https://doi.org/10.21203/rs.3.rs-52169/v1

License: (9) (1) This work is licensed under a Creative Commons Attribution 4.0 International License. Read Full License 


\section{Abstract}

Background: Oxidative stress (OS) participates in the pathophysiology of patients with septic shock having multiple organ failure (MOF), ischemia-reperfusion injury and acute respiratory failure syndrome (ARDS). Antioxidants have been proposed in their therapy.

Objective: To evaluate the effect of antioxidant treatment in patients with septic shock with MOF and levels OS after treatment.

Research question: Will the administration of specific antioxidant therapy decrease deregulatory factors of oxidative stress and organ failure in patients with septic shock?

Study design and Methods: Double-blind, placebo-controlled randomized clinical trial run in 2 ICU in Mexico City between May 2018 and January 2020. The random allocation sequence was generated using computer methods. Patients older than 18 years of either sex, with septic shock were included, were excluded when informed consent could not be obtained, they received chronic or recent use of steroids, statins, or antioxidants or if they had contraindications to the use of antioxidants. All antioxidants were administered by mouth or nasogastric tube during 5 days and were added to standard.

Results: 97 patients were included with median age of 66 years. 20 were treated with MT and 18 with Vit $C$ and they showed post-treatment decreased SOFA scores [ $\mathrm{p}=0.007$ and $p<0.001$ respectively]. Also, total antioxidant capacity (TAC) was improved by NAC. All patients had decreased basal levels of Vit $\mathrm{C}$ and patients that received Vit $\mathrm{C}$ had decreased levels of the $\mathrm{NO}_{3}{ }^{-} / \mathrm{NO}_{2}{ }^{-}(\mathrm{p}=0.02)$ and RCP levels $[\mathrm{p}=0.045]$. Procalcitonin (PCT) levels were reduced by Vit $E$, [p=0.047], NAC; [p=0.001] and MT [p=0.045]. LPO was reduced in patients that received MT $p=0.042$

Conclusion: In septic shock, antioxidant therapy associated with standard intensive care unit therapy reduces MOF, the oxidative and inflammatory state. These results could be a reference to use adjuvant antioxidant therapy in patients with septic shock in COVID19.

Trial Registration: ClinicalTrials.gov Identifier: NCT 03557229

\section{Introduction}

Damage caused by OS participates in the pathophysiology of serious diseases like MOF due to sepsis. Bacteria, fungi and viruses or a combination of them cause these diseases (1). Sepsis and septic shock are the largest cause of mortality worldwide in the Intensive Care Units (ICU), MOF (2) constituting a high cost to in health systems (3).

Studies in animal models and in patients with septic shock have shown an imbalance between the production of reactive oxygen species (ROS), reactive nitrogen species (RNS) and antioxidant defenses $(4-6)$. 
In sepsis, ROS are generated by phagocytic cells, by the increased activity of enzymes such as NAD(P)H oxidase, xanthine oxidase and inducible nitric oxide (iNOS) and by increased inflammatory mediators through the activation of nuclear factor KB (NFKB) (7). Mitochondrial damage caused by OS is a component of the pathophysiology of MOF secondary to sepsis (8).

Antioxidants such as N-acetylcysteine (NAC), melatonin (MT), vitamins ( $\mathrm{A}, \mathrm{C}$ and $\mathrm{E}$ ), enzyme cofactors (selenium and zinc) and endogenous compounds (ubiquinone, a lipoic acid, bilirubin, albumin, ferritin, and quercetin) inhibit ROS and RNS, by counteracting their effects (9).

NAC has anti-inflammatory and antioxidant properties $(10,11)$. Its antioxidant capacity is due to the replenishment of glutathione (GSH) deposits and to sequestration of ROS (12). NAC improves hemodynamic variables, cardiac indexes (13) oxygenation, compliance of lung statics, hepatosplenic flow and liver function in septic shock. Thus, NAC decreases MOF (14) and reduces levels of IL-8, soluble a receptor tumor necrosis factor p55 (15), IL-6 and ICAM-1 (16). NAC reduces mechanical ventilation length, days in ICU stay and mortality (17).

Vit C prevents the excessive production of nitric oxide (NO), decreases vasoconstriction and loss of vascular permeability. (18). Decreased Vit $C$ levels are related to severity of MOF and mortality (19). Vit C therapy decreases SOFA scores, PCT, C-reactive protein (CRP) and thrombomodulin leading to a lower mortality rate (20).

$\mathrm{E}(\mathrm{Vit} \mathrm{E})$ is an important lipophilic antioxidant in cell membranes. It protects them from lipid peroxidation (LPO), (21). In septic patients with decreased levels of Vit $\mathrm{E}$ and $\mathrm{O}_{2}{ }^{-}$overproduction, the administration of Vit $E$ and simvastatin inactivates $\mathrm{NAD}(\mathrm{P}) \mathrm{H}$ oxidase (22).

MT lowers OS both at the plasma and intracellular membranes due to its hydrophilic and lipophilic properties. MT possesses ROS sequestration properties, thus protecting cell membrane lipids, cytosol proteins, and nuclear and mitochondrial DNA (23-25).

Recently, there has been an increase in the prevalence and incidence of sepsis and septic shock due to the current pandemic caused by SARS-CoV2 $(26,27)$.

Although there is a marked increase in ROS and a decrease in endogenous antioxidant defenses in critically ill patients with sepsis (28), the usefulness of different antioxidants has not yet been evaluated through clinical-randomized trials. In this study we evaluated the antioxidant effect of Vit C, Vit E, NAC and MT in patients with septic shock through the Sequential Organ Failure Assessment (SOFA) score and the measurement of antioxidant markers and OS.

\section{Methods}

This was a double- blind study in 2 ICU in Mexico City with a parallel randomized group. 


\section{Study Population}

Patients were admitted to the ICU with a primary diagnosis of septic shock. All diagnostic criteria for septic shock were based on the Sepsis-3 consensus (29) which had to be fulfilled within a maximum of 24 hours prior to enrollment, with an acute increase of at least 2 points in the SOFA score (30), lactate level greater than $2 \mathrm{mmol} / \mathrm{L}$ and patients were dependent on a vasopressor for at least 2 hours at the time of enrollment. Exclusion occurred when they were younger than 18 years, not able to grant an informed consent, refused to be included, if they were under chronic use (last 6th months) or recent use of steroids, statins or antioxidants, any contraindication for the use of Vit C, Vit E, NAC o MT of if pregnant or breastfeeding.

Ethical approval was obtained from the local ethics committee (PT 10-0-76; ABC 18-19). Written informed consent for enrollment or consent to continue and use patient data was obtained from each patient or their legal surrogate.

\section{Randomization, Masking, and Drug Administration}

The random allocation sequence was generated at the coordinating center using computer-generated random program. (Fig. 1). Blinding was maintained by the investigational pharmacy at each institution. Investigators were blinded from the onset until the analysis outcomes were completed.

Administration of all antioxidants was by mouth or nasogastric tube for 5 days. Tablets of $600 \mathrm{mg}$ every 12 hours of NAC were used. MT capsules of $5 \mathrm{mg}$ were given to patients $50 \mathrm{mg}$ once a day. Vit C $1 \mathrm{gm}$ tablets every 6 hours were given. We used Vit E capsules of $400 \mathrm{Ul}$ every 8 hours. Patients of the control group did not receive any type of therapy. All data entry was monitored at the coordinating center, with site visits for source data verification.

\section{Standard therapy at the ICU}

Patients were treated according to the recommendation of the International Guidelines for Management of Sepsis and Septic Shock (30).

\section{Outcomes}

Primary outcome was SOFA scores for up to 5 days. There were 14 pre-specified secondary outcomes, including plasma OS markers (nitrate/nitrite $\left(\mathrm{NO}_{3}{ }^{-} / \mathrm{NO}_{2}{ }^{-}\right), \mathrm{LPO}, \mathrm{GHS}$ levels, TAC, carbonylation and Vit C levels) at 48 hours. Secondary outcomes were measured on day 28 including mortality due to any cause, ventilator-free days, ICU-free days, and hospital-free days. Ventilator-free days were defined as the number of days a patient was extubated from mechanical ventilation, after ICU admission and requiring reintubation were subtracted from the total days. If the patient died in the hospital, a value of zero was 


\section{Study Measurements and Procedures}

To evaluate the organ dysfunction, SOFA score (neurologic, respiratory, hemodynamic, hepatic, and hematologic) was calculated at admission and during all days of treatment. The CRP and the PCT determinations were performed on admission before the beginning of the antioxidant therapy and during the next 7 days.

\section{Sampling for the determination of oxidative stress and antioxidant state}

The measurement of OS markers was done before the beginning of the antioxidant therapy and 48 hours after its initiation.

\section{Sample obtention and storage}

Blood samples were obtained from each patient entered to the draw, before initiation of the treatment and 48 hours after it began. The plasma of the samples was placed in 3 or 4 aliquots and was stored at $-70^{\circ} \mathrm{C}$.

\section{Oxidative stress markers}

\section{Nitrates and nitrites}

The $\mathrm{NO}_{3}{ }^{-}$was reduced to $\mathrm{NO}_{2}{ }^{-}$by the nitrate reductase enzyme reaction. At the end of the incubation period $200 \mu \mathrm{l}$ of sulfanilamide $\%$ and $200 \mu \mathrm{l}$ of $\mathrm{N}$-naphthyl-ethyldiamine $0.1 \%$ were added and the total volume was adjusted to $1 \mathrm{ml}$. The absorbance was measured at $540 \mathrm{~nm}$.

\section{Lipid Peroxidation}

$50 \mu \mathrm{CH} 3-\mathrm{OH}$ with $4 \% \mathrm{BHT}$ plus phosphate buffer $\mathrm{pH} 7.4$ was added to $100 \mu$ of plasma. It was incubated, centrifuged at $4000 \mathrm{rpm}$ at room temperature for $2 \mathrm{~min}$. Then the $\mathrm{n}$-butanol phase was extracted, the absorbance was measured at $532 \mathrm{~nm}$.

\section{Glutathione concentration}


$800 \mu \mathrm{l}$ of phosphate buffer $50 \mathrm{mM}, \mathrm{pH} 7.3$, plus $100 \mu$ of Ellman reactive (5,5' dithiobis 2-nitrobenzoic) $1 \mathrm{M}$, were added to $100 \mu \mathrm{g}$ of plasma previously deproteinization with $20 \%$ trichloroacetic acid ( $\mathrm{vol} / \mathrm{vol})$. It was incubated at room temperature and absorbance was read at $412 \mathrm{~nm}$.

\section{Evaluation of total antioxidant capacity}

$100 \mu$ l of plasma were suspended in $1.5 \mathrm{~mL}$ of a reaction mixture prepared as follows: $300 \mathrm{mM}$ acetate buffer $\mathrm{pH}$ 3.6, $20 \mathrm{mM}$ hexahydrate of ferric chloride, and $10 \mathrm{mM}$ of 2,4,6-Tris-2- pyridil-s-triazine dissolved in $40 \mathrm{mM}$ chlorhydric acid. These reactives were added in a relation of 10:1:1 v/v, respectively. After mixing samples were incubated at $37^{\circ} \mathrm{C}$ for $15 \mathrm{~min}$ in the dark. The absorbance was measured at $593 \mathrm{~nm}$.

\section{Carbonylation}

$100 \mu \mathrm{l}$ of plasma were added to $500 \mu \mathrm{l}$ of $\mathrm{HCl} 2.5 \mathrm{~N}$ in parallel with another sample with $500 \mu \mathrm{l}$ of 2, 4dinitrophenylhydrazine (DNPH), and incubated. At the end of the incubation period, they were centrifuged at $15,000 \mathrm{~g}$ for $5 \mathrm{~min}$. The supernatant was discarded. Two washings were performed. The mixture was incubated again at $37^{\circ} \mathrm{C}$ for $30 \mathrm{~min}$. Absorbance was read in a spectrophotometer at $370 \mathrm{~nm}$, using water bi-distilled as blank and a molar absorption coefficient of $22000 \mathrm{M}^{-1} \mathrm{~cm}^{-1}$.

\section{Vitamin C}

$100 \mu \mathrm{l}$ of $20 \%$ trichloroacetic acid was added to $100 \mu \mathrm{L}$ of plasma., centrifuged at $5000 \mathrm{rpm}$ for $5 \mathrm{~min}$. $200 \mu \mathrm{l}$ of Folin-Ciocalteu reagent $0.20 \mathrm{mM}$ was added to the supernatant. The mixture was incubated for $10 \mathrm{~min}$. The absorbance was measured at $760 \mathrm{~nm}$.

\section{Statistical Analysis}

Based on a SD of 2.9 of the SOFA score, the study estimated to require 55 (11 per group) patients to have $84 \%$ power (2- sided with an $\alpha=0.05$ ) and 160 (32 per group). In accordance with these calculations, our study enrolled 97 patients to allow for $10 \%$ dropouts, providing a statistical power of $99 \%$, with an $a<.05$. Testing was 2 sided. Effects are reported with a point estimate and $95 \% \mathrm{Cls}$ in addition to $P$ values.

Group comparisons were made using $\chi 2$ tests for equal proportions, $t$ tests for normally distributed data, Kruskal Wallis and Wilcoxon rank sum tests otherwise, with results presented as frequencies with percentages, means with SDs, and medians with minimum and maximum, respectively.

The primary end point SOFA score and secondary end points (PCR and PCT) were analyzed with a mixed linear model and fit to repeated-measures analysis of variance. The model included 1 between-participant factor (group [Vit C, Vit E, NAC, MT, no treatment]), 1 within-participant factor (time $[0,1,2,3,4$, and 5 
days]), and the interaction between group and time, testing the hypothesis that differences between treatment groups are the same over time. Because of a potential for type I error caused by multiple comparisons, findings for analyses of secondary end points should be interpreted as exploratory. Statistical analysis was performed with Stata version 15.1 .

\section{Results}

\section{Characteristics of the Patients}

From July 2018 to November 2019 a total of 1695 eligible patients were identified, of whom 1598 were excluded (reasons listed in Fig. 1). Ninety-seven patients were randomized, with 18 assigned to each antioxidant and 21 to the control group. Of all patients included none was lost in the follow up. Baseline demographic data (eg, age, sex) were similar between the groups (Table 1). 
Table 1

Baseline Participant Characteristics

\begin{tabular}{|c|c|c|c|c|c|}
\hline Characteristics & $\begin{array}{l}\text { Vit C } \\
(n=18)\end{array}$ & $\begin{array}{l}\text { Vit E } \\
(n=18)\end{array}$ & $\begin{array}{l}\text { NAC } \\
(n=20)\end{array}$ & $\begin{array}{l}\text { MT } \\
(n=20)\end{array}$ & $\begin{array}{l}\text { Control } \\
(n=21)\end{array}$ \\
\hline Age, median (min-max), y & $\begin{array}{l}62(22- \\
95)\end{array}$ & $\begin{array}{l}65.5 \\
(22-91)\end{array}$ & $\begin{array}{l}67.5(18- \\
95)\end{array}$ & $\begin{array}{l}62.5(46- \\
95)\end{array}$ & $\begin{array}{l}76(51- \\
89)\end{array}$ \\
\hline Weight, median (min-max), & $\begin{array}{l}71(33- \\
112)\end{array}$ & $\begin{array}{l}71.5 \\
(40-120)\end{array}$ & $\begin{array}{l}69.5(39- \\
95)\end{array}$ & $\begin{array}{l}67(50- \\
106)\end{array}$ & $\begin{array}{l}68(50- \\
105)\end{array}$ \\
\hline $\begin{array}{l}\text { BMI, median (min-max), } \\
\text { weight/height }^{2}\end{array}$ & $\begin{array}{l}25.4 \\
(14.7- \\
40.4)\end{array}$ & $\begin{array}{l}25 \\
(15.1- \\
41.4)\end{array}$ & $\begin{array}{l}22.45 \\
(16.5- \\
30.3)\end{array}$ & $\begin{array}{l}25.35 \\
(17.3-52)\end{array}$ & $\begin{array}{l}25.4 \\
(19.6-58)\end{array}$ \\
\hline Sex, No. (\%) & $6(6.19)$ & \multirow{2}{*}{$\begin{array}{l}12 \\
(12.37) \\
6(6.19)\end{array}$} & $11(11.34)$ & & \multirow{2}{*}{$\begin{array}{l}10 \\
(10.31) \\
11 \\
(11.34)\end{array}$} \\
\hline $\begin{array}{l}\text { Men } \\
\text { Women }\end{array}$ & $\begin{array}{l}12 \\
(12.37)\end{array}$ & & $9(9.28)$ & $10(10.31)$ & \\
\hline Chronic health condition, No. (\%) & $4(4.12)$ & $4(4.12)$ & $3(3.09)$ & $5(5.15)$ & $6(6.19)$ \\
\hline Diabetes Mellitus & $6(6.19)$ & $8(8.25)$ & $9(9.28)$ & $7(7.22)$ & \multirow{3}{*}{$\begin{array}{l}11 \\
(11.34) \\
11 \\
(11.34)\end{array}$} \\
\hline Hypertension & $5(5.15)$ & $9(9.28)$ & $7(7.22)$ & $7(7.22)$ & \\
\hline Cancer & $1(1.03)$ & $2(2.03)$ & $4(4.12)$ & $3(3.09)$ & \\
\hline Chronic renal failure & & & & & $2(2.06)$ \\
\hline Admission source, No. (\%) & $9(9.28)$ & \multirow{4}{*}{$\begin{array}{l}12 \\
(13.37) \\
2(2.06) \\
4(4.12) \\
0\end{array}$} & $10(10.31)$ & $14(14.43)$ & $9(9.28)$ \\
\hline Emergency department & $4(4.12)$ & & $3(3.09)$ & $2(2.06)$ & $4(4.12)$ \\
\hline Operating room & $3(3.09)$ & & $7(7.22)$ & $4(4.12)$ & $7(7.22)$ \\
\hline $\begin{array}{l}\text { Inpatient ward transfer } \\
\text { Other }\end{array}$ & $2(2.06)$ & & 0 & 0 & $1(1.03)$ \\
\hline Primary site of infection, No. (\%) & $7(7.37)$ & $9(9.97)$ & $9(9.97)$ & $8(8.42)$ & $6(6.32)$ \\
\hline Pulmonary & $7(7.37)$ & $3(3.16)$ & $4(4.21)$ & $3(3.16)$ & $9(9.97)$ \\
\hline Gastrointestinal & $2(2.11)$ & $2(2.11)$ & $5(5.26)$ & $5(5.26)$ & $3(3.16)$ \\
\hline Urinary & 0 & $2(2.11)$ & 0 & 0 & $1(1.05)$ \\
\hline CNS & 0 & $1(1.05)$ & 0 & $2(2.11)$ & 0 \\
\hline Blood & & & & & \\
\hline
\end{tabular}




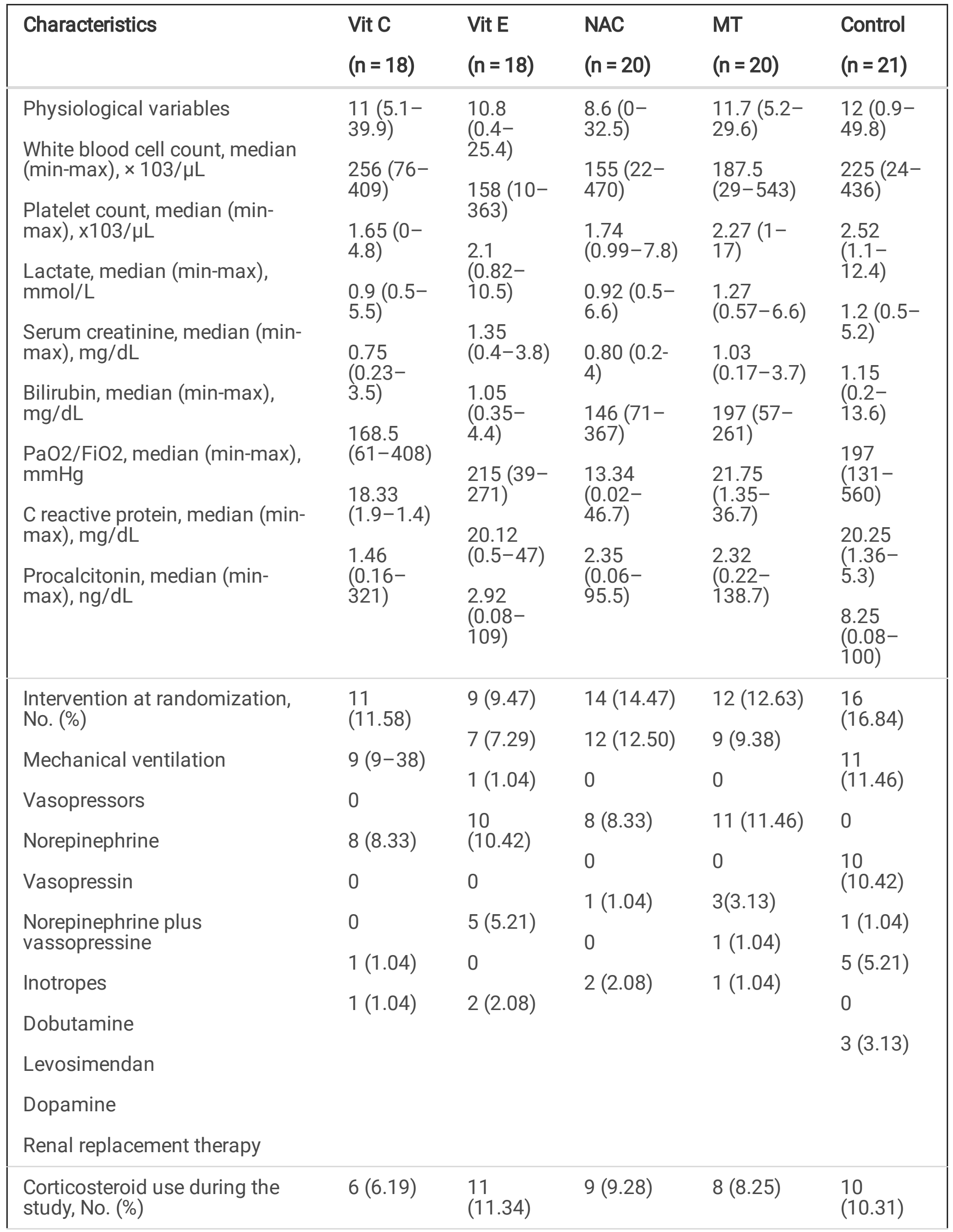




\begin{tabular}{|c|c|c|c|c|c|}
\hline Characteristics & $\begin{array}{l}\text { Vit C } \\
(n=18)\end{array}$ & $\begin{array}{l}\text { Vit E } \\
(n=18)\end{array}$ & $\begin{array}{l}\text { NAC } \\
(n=20)\end{array}$ & $\begin{array}{l}\text { MT } \\
(n=20)\end{array}$ & $\begin{array}{l}\text { Control } \\
(n=21)\end{array}$ \\
\hline SAPS II, median (min-max) & $\begin{array}{l}38(16- \\
62)\end{array}$ & $\begin{array}{l}40(24- \\
73)\end{array}$ & $\begin{array}{l}38.5(12- \\
97)\end{array}$ & $\begin{array}{l}41.5(13- \\
73)\end{array}$ & $\begin{array}{l}40(18- \\
79)\end{array}$ \\
\hline APACHE III, median (min-max) & $\begin{array}{l}13.5(5- \\
47)\end{array}$ & $\begin{array}{l}19(11- \\
33)\end{array}$ & $\begin{array}{l}14.5(5- \\
46)\end{array}$ & $\begin{array}{l}17 \\
(6-39)\end{array}$ & $\begin{array}{l}15 \\
(5-38)\end{array}$ \\
\hline SOFA score, median (min-max) & $\begin{array}{l}8.5(3- \\
16)\end{array}$ & $\begin{array}{l}8.5(5- \\
14)\end{array}$ & $8.5(1-17)$ & $8(3-14)$ & $8(1-16)$ \\
\hline $\begin{array}{l}\text { Time from ICU admission } \\
\text { to randomization, median (min- } \\
\text { max), h }\end{array}$ & $\begin{array}{l}5(1.5- \\
70)\end{array}$ & $6(1-17)$ & $3(1-140)$ & $9(3-48)$ & - \\
\hline $\begin{array}{l}\text { Abbreviations: Vit C: vitamin C; } \\
\text { minimum - maximum; BMl: bod } \\
\text { Acute Physiology Score; APACHE } \\
\text { Organ Failure Assessment; ICU: }\end{array}$ & $\begin{array}{l}\text { vitamin } \\
\text { ass inde } \\
\text { ute Phy } \\
\text { sive cal }\end{array}$ & $\begin{array}{l}\text { C: n-ace } \\
\text { S: centra } \\
\text { y and } \mathrm{Cl}\end{array}$ & $\begin{array}{l}\text { Isteine; MT } \\
\text { rvous syste } \\
\text { ic Health E }\end{array}$ & $\begin{array}{l}\text { latonin; } \\
\text { APS II: } \\
\text { ation; SO }\end{array}$ & $\begin{array}{l}\text { mx): } \\
\text { lified } \\
\text { Sequential }\end{array}$ \\
\hline
\end{tabular}

\section{Treatments}

Treatments were given for a median of 5 days. The median of adherence in the 4 different groups of treatment was $100 \%$. There was no difference between groups in the time from meeting eligibility criteria to the first dose, time receiving the treatment and the adherence.

\section{Primary outcome}

Patients receiving MT and Vit $\mathrm{C}$ showed a significant decrease in SOFA score [-1.27 (95\% $\mathrm{Cl}-2.21$ to -0.34 ); $p=0.007$ for MT and -1.94 (95\% Cl -2.95 to -0.93 ); $p<0.001$ for Vit C] (Fig. 2).

\section{Secondary outcome}

OS marker levels before and after 48 hours of antioxidant therapy are shown (Table 2). The LPO levels were significantly reduced in patients treated with $\mathrm{MT}$ and there was a significant decrease in $\mathrm{NO}_{3}{ }^{-} / \mathrm{NO}_{2}{ }^{-}$ levels in patients with lung infection treated with Vit C. 
Table 2

Oxidative stress markers before and after 48 hours of antioxidant therapy.

\section{Lipid Peroxidation, nM MDA/ml}

$\begin{array}{llll}\text { Group } & \text { Pre } & \text { Post } & p \\ \text { Vit. C }(n=18) & 3.44(0.52-19.62) & 2.81(0.23-8.70) & 0.14 \\ \text { Vit. E }(n=18) & 4.33(1.25-15.25) & 3.24(0.38-12.07) & 0.17 \\ \text { NAC }(n=20) & 3.46(0.23-9.49) & 3.46(0.38-11.01) & 0.77 \\ \text { MT }(n=20) & 2.13(0.23-11.68) & 2.42(0.23-7.11) & 0.04 \\ \text { Control }(n=21) & 3.44(0.52-9.49) & 3.90(0.23-9.10) & 0.75\end{array}$

\section{Nitrates and nitrite, $\mu \mathrm{M} / \mathrm{mL}$}

\begin{tabular}{llll} 
Group & Pre & Post & $p$ \\
Vit C $(\mathrm{n}=18)$ & $2.10(0.98-2.73)$ & $1.49(0.03-2-57)$ & $<0.01$ \\
$\operatorname{Vit} \mathrm{E}(\mathrm{n}=18)$ & $1.79(0.53-3.81)$ & $2.00(0.76-5.65)$ & 0.36 \\
NAC $(\mathrm{n}=20)$ & $2.43(0.80-7.02)$ & $2.15(0.01-8.16)$ & 0.81 \\
MT $(\mathrm{n}=20)$ & $1.72(0.67-4.77)$ & $1.32(0.03-7.42)$ & 0.19 \\
\hline Control $(\mathrm{n}=21)$ & $2.25(0.28-2.76)$ & $2.24(0.01-7.22)$ & 0.97
\end{tabular}

\section{Total antioxidant capacity, $\mathrm{nM} / \mathrm{ml}$}

\begin{tabular}{llll} 
Group & Pre & Post & $p$ \\
\hline Vit C $(\mathrm{n}=18)$ & $2226.2(747.6-3053.4)$ & $2050.9(966.6-2551.8)$ & 0.11 \\
\hline Vit E $(\mathrm{n}=18)$ & $2148.4(886.3-3287.6)$ & $2223.1(618.3-3841.9)$ & 0.90 \\
\hline NAC $(\mathrm{n}=20)$ & $1453.6(621.5-2351.4)$ & $1951(812.6-3528.7)$ & 0.05 \\
MT $(\mathrm{n}=20)$ & $1999(561.3-2519.2)$ & $1747.5(456.5-2745.6)$ & 0.59 \\
\hline Control $(\mathrm{n}=21)$ & $2451.6(1600-3467.1)$ & $2064.7(312.4-3501)$ & 0.42
\end{tabular}

\section{Carbonylation, $\mathrm{ng} / \mathrm{mL}$}

\begin{tabular}{|llll|} 
Group & Pre & Post & $p$ \\
\hline Vit C $(n=18)$ & $48.85(10.90-114.53)$ & $44.76(12.72-98.17)$ & 0.59 \\
\hline Vit E $(n=18)$ & $52.26(27.27-137.25)$ & $42.723(21.36-89.53)$ & 0.07 \\
\hline NAC $(n=20)$ & $40.22(22.27-89.99)$ & $41.13(22.72-93.17)$ & 0.47 \\
\hline MT $(n=20)$ & $74.76(8.63-181.34)$ & $62.721(29.99-142.25)$ & 0.40 \\
\hline Control $(n=21)$ & $46.359(9.99-106.80)$ & $44.08(26.36-111.80)$ & 0.28 \\
\hline
\end{tabular}




\section{Lipid Peroxidation, nM MDA/ml}

\section{Glutathione concentration, $\mathrm{nM} / \mathrm{ml}$}

\begin{tabular}{|c|c|c|c|}
\hline Group & Pre & Post & $p$ \\
\hline Vit $C(n=18)$ & $0.10(0.01-0.24)$ & $0.08(0.01-0.20)$ & 0.50 \\
\hline Vit $E(n=18)$ & $0.05(0.00-0.30)$ & $0.07(0.00-0.32)$ & 0.38 \\
\hline NAC $(n=20)$ & $0.08(0.00-0.54)$ & $0.10(0.009-0.57)$ & 0.14 \\
\hline Melat $(n=20)$ & $0.07(0.00-0.32)$ & $0.07(0.010-0.51)$ & 0.64 \\
\hline Control $(n=21)$ & $0.06(0.03-0.20)$ & $0.05(0.01-0.16)$ & 0.15 \\
\hline \multicolumn{4}{|c|}{ Vitamin $\mathrm{C}, \mu \mathrm{M} / \mathrm{mL}$} \\
\hline Group & Pre & Post & $p$ \\
\hline Vit $C(n=18)$ & $0.17(0.04-0.87)$ & $0.27(0.06-.99)$ & $<0.01$ \\
\hline Vit $E(n=18)$ & $0.27(0.08-0.99)$ & $0.26(0.12-0.79)$ & 0.58 \\
\hline NAC $(n=20)$ & $0.21(0.09-0.61)$ & $0.18(0.00-0.96)$ & 1.00 \\
\hline $\mathrm{MT}(\mathrm{n}=20)$ & $0.21(0.04-0.56)$ & $0.21(0.04-0.43)$ & 0.83 \\
\hline Control $(n=21)$ & $0.22(0.08-0.77)$ & $0.19(0.07-0.64)$ & 0.02 \\
\hline
\end{tabular}

Patients receiving Vit $\mathrm{C}$ had a significant decrease in CRP levels per day of treatment (Fig. 3). PCT levels were significantly decreased in patients receiving Vit E, NAC, and MT (Fig. 4). Vit E showed a tendency to reduce levels before and after treatment of LPO and of carbonylation.

Regarding the secondary outcomes, 13 patients (13.68\%) required renal replacement therapy, 63 (65.63\%) mechanical ventilation and $17(17.89 \%)$ died. There was no statistically significant difference in days free of renal replacement therapy, mechanical ventilation, ICU stay length or hospitalization at 28 days. There was also no statistically significant difference in intrahospital mortality.

\section{Undesired side effects}

A patient receiving Vit $\mathrm{C}$ presented abdominal pain and another patient underwent a skin rash. Only one patient who received MT reported drowsiness. No adverse events were reported in patients with NAC or Vit E.

\section{Discussion}


Treatment with antioxidants as an adjuvant in the standard management of patients with sepsis, septic shock and infection with COVID-19 has been suggested (31-34). We studied critically ill patients with septic shock regardless of the etiology and site of infection. All patients had initial low levels of Vit C, which was related with the severity of organ failure and mortality (18). The decrease in Vit C levels confirms the reported hypovitaminosis ( $<0.23 \mu \mathrm{M}$ ascorbic $\mathrm{ac} / \mathrm{mL})$ in septic shock (34-37). It may be due to augmented metabolic demand, since intestinal absorption is not compromised in the patients in our study. (36). Vit $\mathrm{C}$ restored the normal values of this vitamin and organ function was improved. The best result was found in subjects with pneumonia with significant difference. This finding is in agreement with previous results (38-40). The combined use of Vit C, thiamine and steroids has recently been suggested. It is still necessary to compare if the use of Vit $\mathrm{C}$ alone has worse effects than the combinations (41).

In patients with septic shock, the administration of Vit $\mathrm{C}$ and MT improved the organ dysfunction assessed by the SOFA score. This finding could be associated to a decrease in the $\mathrm{NO}_{3}{ }^{-} / \mathrm{NO}_{2}{ }^{-}$and $\mathrm{LPO}$ levels.

The CITRIS-ALI study in patients with acute respiratory failure syndrome, ARFS, and organ failure showed no improvement with Vit C (42). The median time before starting treatment with Vit $C$ was of 5 hours in this study, and markers such as CPR were significantly decreased, which was similar to another study (43). The possible difference with our results could be related to the fact that in the CITRIS-ALI study they started the therapy with Vit C later.

The VITAMINS trial showed no significant difference in the SOFA score, or in days without ventilation at 28 day; however, the use of Vit C lowered mortality (44). In that same study, CRP levels were not decreased, which was probably due to the late administration of Vit $\mathrm{C}$ in advanced stages of sepsis before developing ARDS (42). In contrast, we found a decrease in the levels of $\mathrm{NO}_{3}{ }^{-} / \mathrm{NO}_{2}{ }^{-}$which is relevant since Vit $\mathrm{C}$ inhibits the production of superoxide $\left(\mathrm{O}_{2}{ }^{-}\right)$and peroxynitrite, thus preventing abundant NO synthesis, inhibiting mRNA expression and decreasing pathological vasoconstriction (17). These effects might be underlying the clinical benefit. A shorter time of use of vasopressors and a decreased intrahospital mortality was found in patient receiving Vit C (45).

This is the first study of the use of MT in humans with septic shock. Recently MT has been applied in subjects with COVID 19 and it has a high safety profile limiting this virus-related disease. Experimental and clinical studies are required to confirm this hypothesis (31). MT possesses free radical scavenging properties thus protecting cell membrane lipids, cytosol proteins, and nuclear and mitocondrial DNA (23, 24). In our findings, LPO was significantly decreased in the group of patients who received MT which was similar to results in the Galley's study (25). MT has beneficial effects in experimental cells, plants, and animals; however, its mechanisms of action remain unknown. The functions of the MT receptor relate to its ability as a detoxification agent, thus protecting molecules from the destructive effects of OS in ischemia/reperfusion (stroke, heart attack), ionizing radiation and drug toxicity. In sepsis, the protective effects of MT are associated with the inhibition of the apoptotic processes and reduction of OS. 
Production of ROS is increased in an animal model of septic shock $(46,47)$. This coincides with a lowering of the TAC and a reduction of the activity of superoxide dismutase and GSH peroxidase (4855). MT reversed morphological damage and increased the activities of antioxidant enzymes $(46,48,61$, $49,53,55-60)$. Therefore, research through blinded clinical trials $(62,63)$ and multicenter studies with adequate amounts of MT are needed to determine the potential of MT. In this clinical trial, we found a reduction of LPO and its potentially beneficial effect in organ dysfunction. Its use as an adjuvant in septic shock reduces inflammation and oxidation in animal models with respiratory damage induced by infection. MT has positive physiological actions, it is effective and safe for patients with septic shock of any etiology including those infected with SARS-CoV2 (31).

The use of NAC improved the antioxidant capacity and tended to increase GSH although the difference was not statistically significant. This confirms its antioxidant effect through the replacement of GSH deposits (12). NAC was related to decreases in organ failure, confirming previous findings (14).

Other antioxidants such as polyphenols, MT, $\beta$-glucan, antioxidants targeting mitochondria, selenium salts, and selenium organ compounds are effective for improving OS in sepsis. The study of their pathophysiological implications justifies the combined therapy with antioxidants and standard treatments.

Vit $E$ tended to decrease LPO and carbonylation. This vitamin protects cell membranes from LPO, ending their chain reaction. It is also an $\mathrm{O}_{2}^{-}$and hydroxyl $(\mathrm{OH})$ sequestrant (64).

In summary, antioxidants benefit subjects with septic shock. Septic shock is triggered by bacterial stimuli, fungi or viruses. In this medical condition, it is necessary to regulate inflammation and other mechanisms that lead to OS (65).

\section{Limitations}

The absorption may be altered by the enteral route of administration. However, we found increments on Vit $\mathrm{C}$ levels in serum.

The present trial is underpowered to detect differences in mortality and in outcomes between groups because the sample size was calculated for differences of OS.

\section{Conclusion}

In patients with septic shock, adding antioxidants to standard therapy regulates inflammation. In pulmonary sepsis, replacement therapy with Vit $C$ increases its serum levels, which is associated with decreased levels of CRP, PCT, and $\mathrm{NO}_{3}{ }^{-} / \mathrm{NO}_{2}{ }^{-}$. MT decreases $\mathrm{LPO}$ and SOFA score. NAC reduces $\mathrm{LPO}$ and improves antioxidant capacity. Vit $\mathrm{E}$ tends to decrease LPO. Each antioxidant has beneficial effect; thus, they might be combined in clinical trials in patients with septic shock. We suggest the use of antioxidants 
as an adjuvant to standard therapy in patients with COVID-19, adjusting for comorbidities and drug interaction.

\section{Abbreviations}

(COVID-19) $=$ Coronavirus infectious disease, $($ OS $)=$ Oxidative stress $($ ICU $)=$ Intensive Care Units, $(\mathrm{MOF})=$ multiple organ failure,(ARDS) $=$ respiratory failure syndrome,(SOFA) score sequential organ failure assessment, (iNOS) inducible nitric oxide, (ROS) reactive oxygen species,(RNS) reactive nitrogen species, (NAC), N-acetylcysteine,(MT) melatonin, (GSH) glutathione, (Vit) Vitamin, $\left(\mathrm{NO}_{3}{ }^{-} / \mathrm{NO}_{2}{ }^{-}\right)$nitrate/nitrite, (LPO) Lipoperoxidation, (CRP) C reactive protein

\section{Declarations}

\section{Availability of data and materials}

The data generated or analyzed during the current study are included in this manuscript and its additional files.

\section{Ethics approval and consent to participate.}

This study was approved by the Ethics Committees of American British Cowdray (ABC) Medical Center, I.A.P., and Instituto Nacional de Cardiologia Ignacio Chavez, informed consents were obtained from all patients

\section{Consent for publication}

Not applicable

\section{Competing interests}

The authors declare that they have no competing interests

\section{Funding}

This study was supported by American British Cowdray (ABC) Medical Center, I.A.P.

\section{Authors' contributions}


AAA: Analysis data collection patient care, laboratory work, protocol work in written master's program and article review. IPT: Conceptualization, design, laboratory elaboration, writing, review and approval for publication. GCA: Patient care, article review. JFG: Patients attention and review of the article. VGL: Participation in conceptualization, written laboratory work and review and approval for publication. EMR: Patient care, database management, laboratory work. RG, Laboratory work, review and approval of the writing. MES: Conceptualization, design, thesis tutor, statistical analysis, preparation of the protocol and manuscript revision and approval of the manuscript.All authors read and approved the final manuscript

\section{Acknowledgements}

Not applicable

\section{References}

1. Timsit J-F, Perner A, Bakker J, Bassetti M, Benoit D, Cecconi M, et al. Year in review in Intensive Care Medicine 2014: III. Severe infections, septic shock, healthcare-associated infections, highly resistant bacteria, invasive fungal infections, severe viral infections, Ebola virus disease and paediatrics. Intensive Care Med 2015;41:575-88. Available at: http://www.ncbi.nlm.nih.gov/pubmed/25810214.

2. Marshall JC, Vincent J-L, Guyatt G, Angus DC, Abraham E, Bernard G, et al. Outcome measures for clinical research in sepsis: a report of the 2nd Cambridge Colloquium of the International Sepsis Forum. Crit Care Med 2005;33:1708-16. Available at:

http://www.ncbi.nlm.nih.gov/pubmed/16096445.

3. Angus DC, Linde-Zwirble WT, Lidicker J, Clermont G, Carcillo J, Pinsky MR. Epidemiology of severe sepsis in the United States: analysis of incidence, outcome, and associated costs of care. Crit Care Med 2001;29:1303-10. Available at: http://www.ncbi.nlm.nih.gov/pubmed/11445675.

4. Chabot F, Mitchell JA, Gutteridge JM, Evans TW. Reactive oxygen species in acute lung injury. Eur Respir J 1998;11:745-57. Available at: http://www.ncbi.nlm.nih.gov/pubmed/9596132.

5. Pisoschi AM, Pop A. The role of antioxidants in the chemistry of oxidative stress: A review. Eur J Med Chem 2015;97:55-74. Available at: http://www.ncbi.nlm.nih.gov/pubmed/25942353.

6. Thannickal VJ, Fanburg BL. Reactive oxygen species in cell signaling. Am J Physiol Lung Cell Mol Physio/ 2000;279:L1005-28. Available at: http://www.ncbi.nlm.nih.gov/pubmed/11076791.

7. Galley HF. Oxidative stress and mitochondrial dysfunction in sepsis. Br J Anaesth 2011;107:57-64. Available at: http://www.ncbi.nlm.nih.gov/pubmed/21596843.

8. Crouser ED. Mitochondrial dysfunction in septic shock and multiple organ dysfunction syndrome. Mitochondrion 2004;4:729-41. Available at: http://www.ncbi.nlm.nih.gov/pubmed/16120428.

9. Gutteridge JM. Lipid peroxidation and antioxidants as biomarkers of tissue damage. Clin Chem 1995;41:1819-28. Available at: http://www.ncbi.nlm.nih.gov/pubmed/7497639. 
10. Schmidt H, Schmidt W, Müller T, Böhrer H, Gebhard MM, Martin E. N-acetylcysteine attenuates endotoxin-induced leukocyte-endothelial cell adhesion and macromolecular leakage in vivo. Crit Care Med 1997;25:858-63. Available at: http://www.ncbi.nlm.nih.gov/pubmed/9187607.

11. Schmidt W, Walther A, Gebhard MM, Martin E, Schmidt H. Influence of N-acetylcysteine treatment on endotoxin-induced microcirculatory disturbances. Intensive Care Med 1998;24:967-72. Available at: http://www.ncbi.nlm.nih.gov/pubmed/9803334.

12. Aruoma OI, Halliwell B, Hoey BM, Butler J. The antioxidant action of N-acetylcysteine: its reaction with hydrogen peroxide, hydroxyl radical, superoxide, and hypochlorous acid. Free Radic Biol Med 1989;6:593-7. Available at: http://www.ncbi.nlm.nih.gov/pubmed/2546864.

13. Rank N, Michel C, Haertel C, Lenhart A, Welte M, Meier-Hellmann A, et al. N-acetylcysteine increases liver blood flow and improves liver function in septic shock patients: results of a prospective, randomized, double-blind study. Crit Care Med2000;28:3799-807. Available at: http://www.ncbi.nlm.nih.gov/pubmed/11153617.

14. Peake SL, Moran JL, Leppard PI. N-acetyl-L-cysteine depresses cardiac performance in patients with septic shock. Crit Care Med 1996;24:1302-10. Available at:

http://www.ncbi.nlm.nih.gov/pubmed/8706483.

15. Spapen H, Zhang H, Demanet C, Vleminckx W, Vincent JL, Huyghens L. Does N-acetyl-L-cysteine influence cytokine response during early human septic shock? Chest 1998;113:1616-24. Available at: http://www.ncbi.nlm.nih.gov/pubmed/9631802.

16. Paterson RL, Galley HF, Webster NR. The effect of N-acetylcysteine on nuclear factor-kappa B activation, interleukin-6, interleukin-8, and intercellular adhesion molecule-1 expression in patients with sepsis. Crit Care Med 2003;31:2574-8. Available at:

http://www.ncbi.nlm.nih.gov/pubmed/14605526.

17. Molnár Z, Shearer E, Lowe D. N-Acetylcysteine treatment to prevent the progression of multisystem organ failure: a prospective, randomized, placebo-controlled study. Crit Care Med 1999;27:1100-4. Available at: http://www.ncbi.nlm.nih.gov/pubmed/10397212.

18. Berger MM, Oudemans-van Straaten HM. Vitamin C supplementation in the critically ill patient. Curr Opin Clin Nutr Metab Care 2015;18:193-201. Available at: http://www.ncbi.nlm.nih.gov/pubmed/25635594.

19. Spoelstra-de Man AME, Grooth H-J de, Elbers PWG, Oudemans-van Straaten HM. Response to "Adjuvant vitamin $\mathrm{C}$ in cardiac arrest patients undergoing renal replacement therapy: an appeal for a higher high-dose". Crit Care 2018;22:350. Available at: http://www.ncbi.nlm.nih.gov/pubmed/30567557.

20. Fowler AA, Syed AA, Knowlson S, Sculthorpe R, Farthing D, DeWilde C, et al. Phase I safety trial of intravenous ascorbic acid in patients with severe sepsis. J Trans/ Med 2014;12:32. Available at: http://www.ncbi.nlm.nih.gov/pubmed/24484547.

21. Traber MG, Atkinson J. Vitamin E, antioxidant and nothing more. Free Radic Biol Med. 2007;43:4-15. 
22. Durant R, Klouche K, Delbosc S, Morena M, Amigues L, Beraud JJ, et al. Superoxide anion overproduction in sepsis: Effects of vitamin E and simvastatin. Shock. 2004;22:34-9.

23. Aydogan S, Betul Yerer M, Goktas A. Melatonin and nitric oxide. J Endocrinol Invest. 2006;29:281-7.

24. Reiter RJ, Tan DX, Manchester LC, Pilar Terron M, Flores LJ, Koppisepi S. Medical implications of melatonin: receptor-mediated and receptor-independent actions. Adv Med Sci 2007;52:11-28. Available at: http://www.ncbi.nlm.nih.gov/pubmed/18217386.

25. Galley HF, Lowes DA, Allen L, Cameron G, Aucott LS, Webster NR. Melatonin as a potential therapy for sepsis: a phase I dose escalation study and an ex vivo whole blood model under conditions of sepsis. J Pineal Res 2014;56:427-38. Available at: http://www.ncbi.nlm.nih.gov/pubmed/24650045.

26. Zhou Y, Zhang Z, Tian J, Xiong S. Risk factors associated with disease progression in a cohort of patients infected with the 2019 novel coronavirus. Ann Palliat Med 2020;9:428-436. Available at: http://www.ncbi.nlm.nih.gov/pubmed/32233642.

27. Zuo M-Z, Huang Y-G, Ma W-H, Xue Z-G, Zhang J-Q, Gong Y-H, et al. Expert Recommendations for Tracheal Intubation in Critically ill Patients with Noval Coronavirus Disease 2019. Chinese Med Sci J = Chung-kuo i hsueh k'o hsueh tsa chih 2020. Available at: http://www.ncbi.nlm.nih.gov/pubmed/32102726.

28. Berger MM, Chioléro RL. Antioxidant supplementation in sepsis and systemic inflammatory response syndrome. In: Critical Care Medicine.Vol 35. Crit Care Med; 2007.

29. Rhodes A, Evans LE, Alhazzani W, Levy MM, Antonelli M, Ferrer R, et al. Surviving Sepsis Campaign: International Guidelines for Management of Sepsis and Septic Shock: 2016. Intensive Care Med 2017;43:304-377. Available at: http://www.ncbi.nlm.nih.gov/pubmed/28101605.

30. Vincent JL, Moreno R, Takala J, Willatts S, Mendonça A, De, Bruining H, et al. The SOFA (Sepsisrelated Organ Failure Assessment) score to describe organ dysfunction/failure. On behalf of the Working Group on Sepsis-Related Problems of the European Society of Intensive Care Medicine. Intensive Care Med 1996;22:707-10. Available at: http://www.ncbi.nlm.nih.gov/pubmed/8844239.

31. Zhang R, Wang X, Ni L, Di X, Ma B, Niu S, et al. COVID-19: Melatonin as a potential adjuvant treatment. Life Sci 2020;250:117583. Available at: http://www.ncbi.nlm.nih.gov/pubmed/32217117.

32. Carr AC. A new clinical trial to test high-dose vitamin C in patients with COVID-19. Crit Care 2020;24:133. Available at: http://www.ncbi.nlm.nih.gov/pubmed/32264963.

33. Marik PE. Hydrocortisone, Ascorbic Acid and Thiamine (HAT Therapy) for the Treatment of Sepsis. Focus on Ascorbic Acid. Nutrients 2018;10. Available at: http://www.ncbi.nlm.nih.gov/pubmed/30441816.

34. Borrelli E, Roux-Lombard P, Grau GE, Girardin E, Ricou B, Dayer J, et al. Plasma concentrations of cytokines, their soluble receptors, and antioxidant vitamins can predict the development of multiple organ failure in patients at risk. Crit Care Med 1996;24:392-7. Available at: http://www.ncbi.nlm.nih.gov/pubmed/8625625.

35. Victor VM, Guayerbas N, Puerto M, la Fuente M, De. Changes in the ascorbic acid levels of peritoneal lymphocytes and macrophages of mice with endotoxin-induced oxidative stress. Free Radic Res 
2001;35:907-16. Available at: http://www.ncbi.nlm.nih.gov/pubmed/11811541.

36. Carr AC, Rosengrave PC, Bayer S, Chambers S, Mehrtens J, Shaw GM. Hypovitaminosis C and vitamin $\mathrm{C}$ deficiency in critically ill patients despite recommended enteral and parenteral intakes. Crit Care 2017;21:300. Available at: http://www.ncbi.nlm.nih.gov/pubmed/29228951.

37. Evans-Olders R, Eintracht $S$, Hoffer LJ. Metabolic origin of hypovitaminosis $C$ in acutely hospitalized patients. Nutrition 26:1070-4. Available at: http://www.ncbi.nlm.nih.gov/pubmed/20018480.

38. Ferreira FL, Bota DP, Bross A, Mélot C, Vincent JL. Serial evaluation of the SOFA score to predict outcome in critically ill patients. JAMA 2001;286:1754-8. Available at: http://www.ncbi.nIm.nih.gov/pubmed/11594901.

39. Joo YM, Chae MK, Hwang SY, Jin S-C, Lee TR, Cha WC, et al. Impact of timely antibiotic administration on outcomes in patients with severe sepsis and septic shock in the emergency department. Clin Exp Emerg Med 2014;1:35-40. Available at: http://www.ncbi.nIm.nih.gov/pubmed/27752550.

40. Jones AE, Trzeciak S, Kline JA. The Sequential Organ Failure Assessment score for predicting outcome in patients with severe sepsis and evidence of hypoperfusion at the time of emergency department presentation. Crit Care Med 2009;37:1649-54. Available at: http://www.ncbi.nIm.nih.gov/pubmed/19325482.

41. Hwang SY, Park JE, Jo IJ, Kim S, Chung SP, Kong T, et al. Combination therapy of vitamin C and thiamine for septic shock in a multicentre, double-blind, randomized, controlled study (ATESS): study protocol for a randomized controlled trial. Trials 2019;20:420. Available at: http://www.ncbi.nlm.nih.gov/pubmed/31296251.

42. Fowler AA, Truwit JD, Hite RD, Morris PE, DeWilde C, Priday A, et al. Effect of Vitamin C Infusion on Organ Failure and Biomarkers of Inflammation and Vascular Injury in Patients With Sepsis and Severe Acute Respiratory Failure: The CITRIS-ALI Randomized Clinical Trial. JAMA 2019;322:12611270. Available at: http://www.ncbi.nlm.nih.gov/pubmed/31573637.

43. Fowler AA, Syed AA, Knowlson S, Sculthorpe R, Farthing D, DeWilde C, et al. Phase I safety trial of intravenous ascorbic acid in patients with severe sepsis. J Trans/ Med 2014;12.

44. Fujii T, Luethi N, Young PJ, Frei DR, Eastwood GM, French CJ, et al. Effect of Vitamin C, Hydrocortisone, and Thiamine vs Hydrocortisone Alone on Time Alive and Free of Vasopressor Support Among Patients With Septic Shock: The VITAMINS Randomized Clinical Trial. JAMA 2020. Available at: http://www.ncbi.nlm.nih.gov/pubmed/31950979.

45. 10.1016/j.chest.2016.11.036

Marik PE, Khangoora V, Rivera R. Hydrocortisone, Vitamin C and Thiamine for the Treatment of Severe Sepsis and Septic Shock: A Retrospective Before-After Study. Chest 2017. Available at: http://dx.doi.org/10.1016/j.chest.2016.11.036.

46. Carrillo-Vico A, Lardone PJ, Naji L, Fernández-Santos JM, Martín-Lacave I, Guerrero JM, et al. Beneficial pleiotropic actions of melatonin in an experimental model of septic shock in mice: regulation of pro-/anti-inflammatory cytokine network, protection against oxidative damage and anti- 
apoptotic effects. J Pineal Res 2005;39:400-8. Available at:

http://www.ncbi.nlm.nih.gov/pubmed/16207296.

47. Wu CC, Chiao CW, Hsiao G, Chen A, Yen MH. Melatonin prevents endotoxin-induced circulatory failure in rats. J Pineal Res 2001;30:147-56. Available at: http://www.ncbi.nlm.nih.gov/pubmed/11316325.

48. Crespo E, Macías M, Pozo D, Escames G, Martín M, Vives F, et al. Melatonin inhibits expression of the inducible NO synthase II in liver and lung and prevents endotoxemia in lipopolysaccharide-induced multiple organ dysfunction syndrome in rats. FASEB J 1999;13:1537-46. Available at: http://www.ncbi.nlm.nih.gov/pubmed/10463945.

49. Wang H, Wei W, Shen Y-X, Dong C, Zhang L-L, Wang N-P, et al. Protective effect of melatonin against liver injury in mice induced by Bacillus Calmette-Guerin plus lipopolysaccharide. World $\mathrm{J}$ Gastroenterol 2004;10:2690-6. Available at: http://www.ncbi.nlm.nih.gov/pubmed/15309720.

50. Yerer MB, Yapislar H, Aydogan S, Yalcin O, Baskurt O. Lipid peroxidation and deformability of red. blood cells in experimental sepsis in rats: The protective effects of melatonin. Clin Hemorheol Microcirc 2004;30:77-82. Available at: http://www.ncbi.nlm.nih.gov/pubmed/15004332.

51. Sener G, Toklu H, Kapucu C, Ercan F, Erkanli G, Kaçmaz A, et al. Melatonin protects against oxidative organ injury in a rat model of sepsis. Surg Today 2005;35:52-9. Available at: http://www.ncbi.nlm.nih.gov/pubmed/15622465.

52. Escames G, Acuña-Castroviejo D, López LC, Tan D, Maldonado MD, Sánchez-Hidalgo M, et al. Pharmacological utility of melatonin in the treatment of septic shock: experimental and clinical evidence. J Pharm Pharmaco/ 2006;58:1153-65. Available at: http://www.ncbi.nIm.nih.gov/pubmed/16945173.

53. Ozdemir D, Uysal N, Tugyan K, Gonenc S, Acikgoz O, Aksu I, et al. The effect of melatonin on endotoxemia-induced intestinal apoptosis and oxidative stress in infant rats. Intensive Care Med 2007;33:511-6. Available at: http://www.ncbi.nlm.nih.gov/pubmed/17186286.

54. Shang Y, Xu S-P, Wu Y, Jiang Y-X, Wu Z-Y, Yuan S-Y, et al. Melatonin reduces acute lung injury in endotoxemic rats. Chin Med J (Engl) 2009;122:1388-93. Available at: http://www.ncbi.nlm.nih.gov/pubmed/19567158.

55. Erbaş O, Ergenoglu AM, Akdemir A, Yeniel A, Taskiran D. Comparison of melatonin and oxytocin in the prevention of critical illness polyneuropathy in rats with experimentally induced sepsis. $J$ Surg Res 2013;183:313-20. Available at: http://www.ncbi.nlm.nih.gov/pubmed/23312812.

56. d'Emmanuele di Villa d'Emmanuele di Villa. Bianca R, Marzocco S, Paola R, Di, Autore G, Pinto A, Cuzzocrea S, et al. Melatonin prevents lipopolysaccharide-induced hyporeactivity in rat. J Pineal Res 2004;36:146-54. Available at: http://www.ncbi.nlm.nih.gov/pubmed/15009504.

57. Escames G, López LC, Tapias V, Utrilla P, Reiter RJ, Hitos AB, et al. Melatonin counteracts inducible mitochondrial nitric oxide synthase-dependent mitochondrial dysfunction in skeletal muscle of septic mice. J Pineal Res 2006;40:71-8. Available at: http://www.ncbi.nlm.nih.gov/pubmed/16313501. 
58. López LC, Escames G, Ortiz F, Ros E, Acuña-Castroviejo D. Melatonin restores the mitochondrial production of ATP in septic mice. Neuro Endocrinol Lett 2006;27:623-30. Available at: http://www.ncbi.nIm.nih.gov/pubmed/17159820.

59. Filippis D, De, luvone T, Esposito G, Steardo L, Arnold GH, Paul AP, et al. Melatonin reverses lipopolysaccharide-induced gastro-intestinal motility disturbances through the inhibition of oxidative stress. J Pineal Res 2008;44:45-51. Available at: http://www.ncbi.nlm.nih.gov/pubmed/18078447.

60. Li Volti G, Musumeci T, Pignatello R, Murabito P, Barbagallo I, Carbone C, et al. Antioxidant potential of different melatonin-loaded nanomedicines in an experimental model of sepsis. Exp Biol Med (Maywood) 2012;237:670-7. Available at: http://www.ncbi.nlm.nih.gov/pubmed/22728708.

61. Ortiz F, Acuña-Castroviejo D, Doerrier C, Dayoub JC, López LC, Venegas C, et al. Melatonin blunts the mitochondrial/NLRP3 connection and protects against radiation-induced oral mucositis. $J$ Pineal Res 2015;58:34-49. Available at: http://www.ncbi.nlm.nih.gov/pubmed/25388914.

62. Korkmaz A, Reiter RJ, Topal T, Manchester LC, Oter S, Tan D-X. Melatonin: an established antioxidant worthy of use in clinical trials. Mol Med 15:43-50. Available at:

http://www.ncbi.nlm.nih.gov/pubmed/19011689.

63. Sánchez-Barceló EJ, Mediavilla MD, Tan DX, Reiter RJ. Clinical uses of melatonin: evaluation of human trials. Curr Med Chem 2010;17:2070-95. Available at:

http://www.ncbi.nlm.nih.gov/pubmed/20423309.

64. Lassnigg A, Punz A, Barker R, Keznickl P, Manhart N, Roth E, et al. Influence of intravenous vitamin E supplementation in cardiac surgery on oxidative stress: a double-blinded, randomized, controlled study. Br J Anaesth 2003;90:148-54. Available at: http://www.ncbi.nlm.nih.gov/pubmed/12538369.

65. Prauchner CA. Oxidative stress in sepsis: Pathophysiological implications justifying antioxidant cotherapy. Burns 2017;43:471-485. Available at: http://www.ncbi.nlm.nih.gov/pubmed/28034666.

\section{Figures}




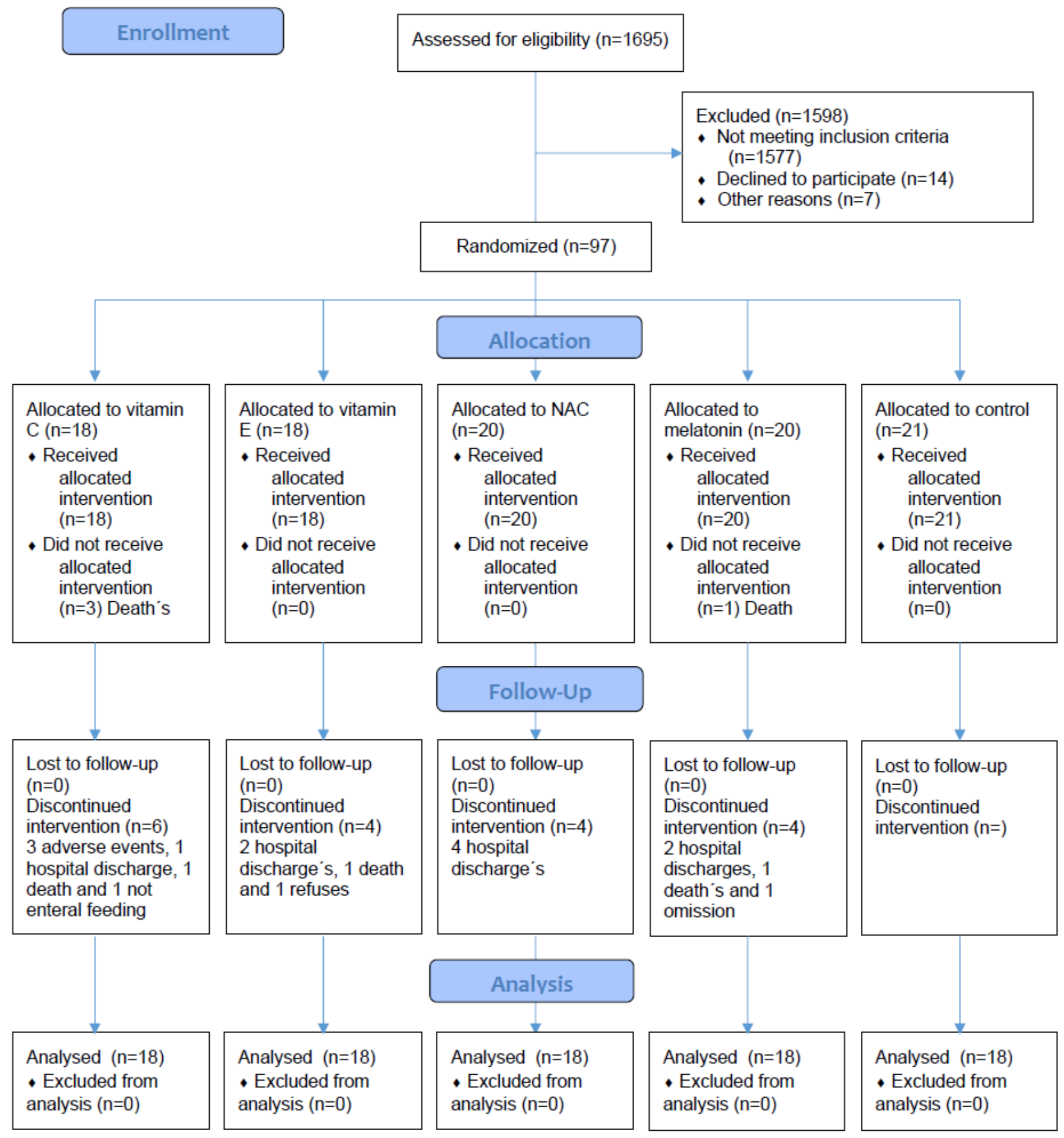

\section{Figure 1}

Flow diagram of the study 


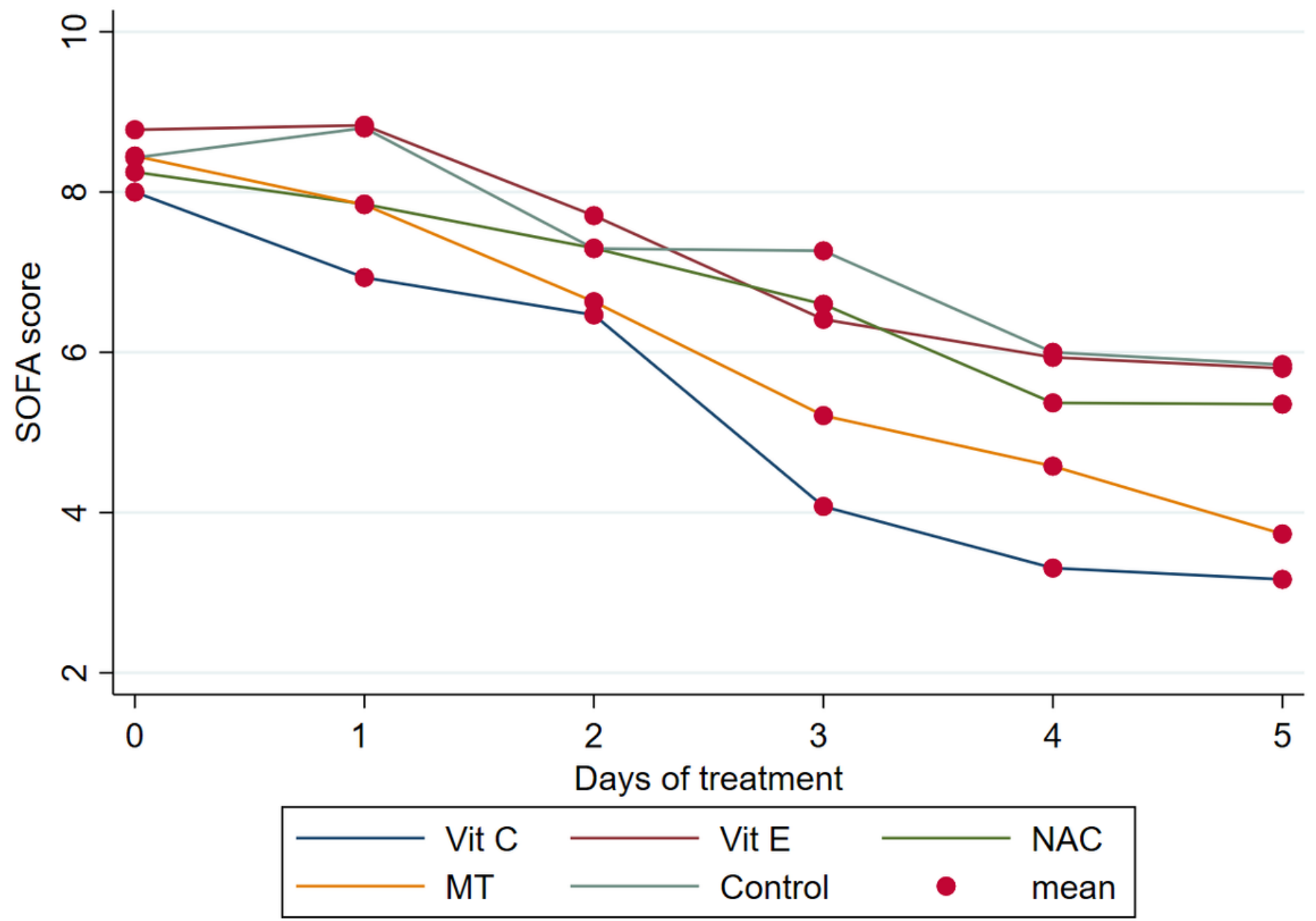

Figure 2

SOFA score in patients: (sequential organ failure assessment); Vit C: vitamin C; Vit E: vitamin E; NAC: $n$ acetilcisteíne; MT; marginal approximation model taking into account the control group as a base: Melat -1.27 (-2.21 a -0.34; $p=0.007)$; Vit C -1.94 (-2.95 a -0.94; $p=<0.001)$. 


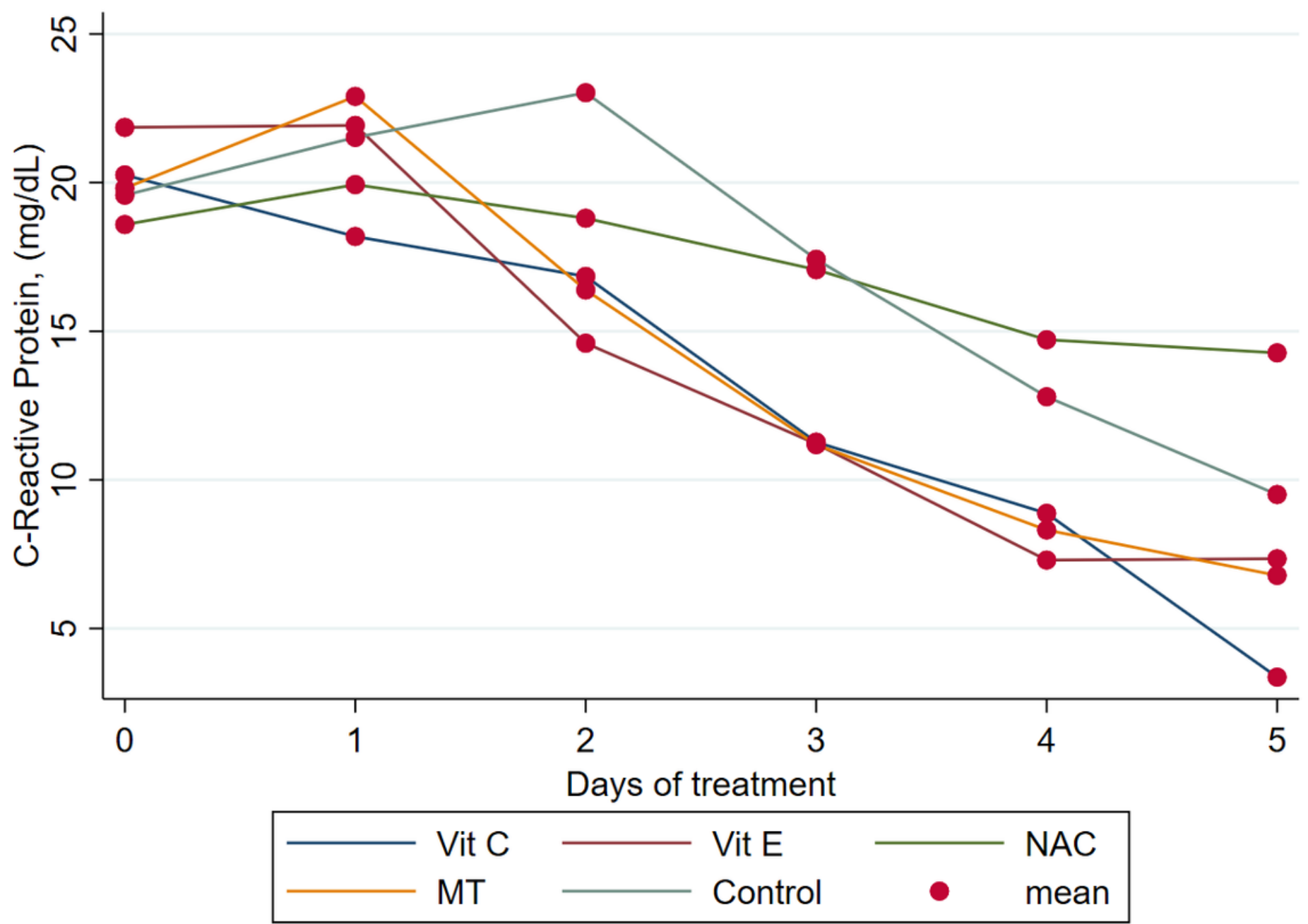

Figure 3

CRP; Vit C; Vit E:; NAC; MT:. Marginal approximation model taking into account the control group as a base: Vit C $-3.82(-7.49$ a $-0.15 ; p=<0.041)$. 


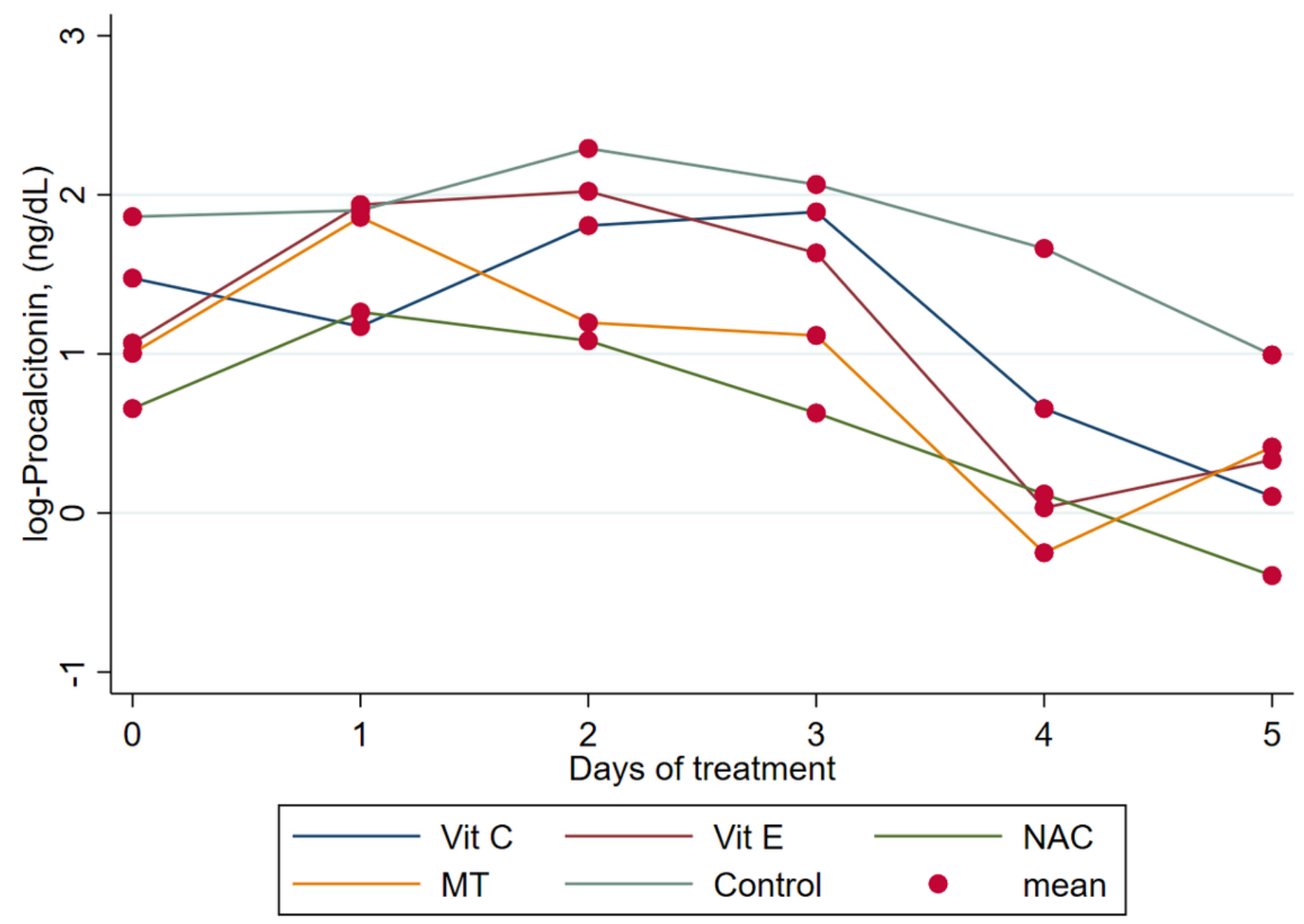

Figure 4

Levels of PCT, Vit C, Vit E,NAC, MT. Marginal approximation model taking into account the control group as a base: Vit E -0.59 (-1.18 a -0.006; $p=<0.047)$; NAC $-0.92(-1.48$ a $-0.35 ; p=0.001)$; MT $-0.57(-1.15$ a $0.006 ; p=0.05)$. 